\title{
TEACHER EDUCATION, A STRATEGY FOR IMPROVING TEACHERS OUTPUT IN NIGERIAN EDUCATIONAL SYSTEM
}

\author{
"Usman, Y. D. \\ *Federal Road Safety CORPS (FRSC), Nassarawa Eggon, Nasarawa State, Nigeria. \\ *Phone: +2348077454456 *Email: usmanyud@gmail.com
}

\begin{abstract}
The quality of teachers in Nigerian education sector has been a source of concern to stakeholders in recent time given that every nation strives towards the provision of quality education for its citizens in realization that education is an essential means to consolidate the nation's developmental progression. The importance of teachers to the socio-economic development of any nation cannot be overemphasized given that teachers are the most important factor in quality education and responsible for the transformation and execution of educational policies and curriculum in line with the expectations of the society. Even though various teacher education courses are offered by different institutions with varying degree of achievement recorded, various problems still confront the programme with far reaching consequences on education system which have invariably affected the quality of products churned out of the education system in Nigeria. This paper examines the influence and relevance of quality teacher education on teacher's efficiency in Nigeria. Some challenges affecting teacher education like inadequate funding, poor policy implementation and lack of motivation were identified. In view of the fact that achieving quality education will be an illusion if teacher education is not in good shape, some solutions to the identified constraints like allocation of adequate funds for the education sector, review of teacher education curriculum, appointment of seasoned educationist as heads of education institutions in the country and regular training and re-training of teachers are also adduced for remediation.
\end{abstract}

Keywords: teacher, teacher education, output, educational system, Nigeria.

LICENSE: This work by Open Journals Nigeria is licensed and published under the Creative Commons Attribution License 4.0 International License, which permits unrestricted use, distribution, and reproduction in any medium, provided this article is duly cited.

COPYRIGHT: The Author(s) completely retain the copyright of this published article.

OPEN ACCESS: The Author(s) approves that this article remains permanently online in the open access (OA) mode.

QA: This Article is published in line with "COPE (Committee on Publication Ethics) and PIE (Publication Integrity \& Ethics)". 


\section{INTRODUCTION}

Teachers are the most important refined human species that skillfully, identify, develop and nurture the potentials of productive citizenry, their quality is critical to the success of education in the society, which implies that the eminence of every community is a correlate of the quality of functional teachers in that society. The effectiveness of all educational arrangements, development and growth lies on teachers' numbers, quality and devotion. In reality, no matter how good an educational design or policy may be, its successful implementation depends on the availability of the right type of teachers. Okebukola (1996) summarizes the importance of the teacher that: the world without teachers is a world without hope, the world without teachers is a world without progress and the world without teachers is a world that is doomed.

Teaching is a complex process aimed at developing the affective, cognitive and psychomotor powers of a learner through the use of appropriate instructive expertise to instill discipline and develop in the learner certain required qualities desirous of future leaders of a prosperous nation. It is therefore, multifaceted and plainly too challenging to be left in the hands of individuals who are not well equipped and knowledgeable to help the learners acquire such manipulative skills. The position of teachers who are the mentors of contemporary and future leaders, managers of knowledge and the main determinants of quality education has been relegated to the background and the honour hitherto accorded teachers and teaching has wane over years. The present-day circumstances in which teachers work without being paid for months or paid in percentages in some states or left without promotion and other fringe benefits is quite bothersome and constitutes a threat to the development of the teaching profession in Nigeria. This worrying scenario has no doubt contributed to the growing dissatisfaction that plagues the teaching profession in the educational system leading to the exodus of quality teaching personnel at all levels of our educational systems in search of greener pastures.

Teaching is observed to be far from being a profession as there is no other career in Nigeria at the moment that is as undervalued as teaching. It is first unable to attract suitably qualified individuals to itself and majority of those who read education did not list education as their first course of study. It is in most cases a second or even worse a last resort (Daily Sun, 2017). Teacher education being inextricably linked with general educational and social goals is constantly caught up in a series of dilemma which develop from unplanned educational expansion and social change (Nakpodia, 2012). In the same way, Oyekan (2006) observed that the prevailing crisis in education and society typified by under-achievement, corruption, indiscipline and underutilization of capacities in all facets of human life and national development could be ascribed to the neglect of general education, teacher education and pitiable plight of the teachers. Ogunjemilua and Adegboye (2014) observed that the Nigerian educational system has witnessed a lot in the area of policy formulation, programmes and recommendations from different task forces, commissions, committees, workshops, seminars, symposia and meetings on how best to produce highly motivated teachers to enable them train and bring up good and competent children.

It is therefore not an exaggeration that making the teacher the centre of educational reform in Nigeria will enhance teachers' productivity, reduce the systemic problems in the educational sector and ensure effective service delivery as well as place education as instrument par excellence for national development (Okemakinde et'al 2014). In view of the fact that nothing in a school has more impact on a learner in terms of skill development, self-competence, 
or classroom behaviour, than the personal and professional growth of the teachers, there is the urgent need for government and relevant stakeholders in the education sector to give teacher education a high-quality foundation so as to improve the performance of teachers who are the pillars of educational development in Nigeria (Ogunyinka etal, 2015).There have been laudable thoughts on the part of the government in its policies to reform the education system but the programmes have not been adequately matched with implementation process to achieve the desired result. A very close examination indicates that a gap still exists in the actual implementation of policies on teacher education resulting in the production of grossly ill-motivated and frustrated teachers in our society (Ekpiken \& Edet, 2014).

Indisputably, if teachers in the nation are not enthused, socially connected, motivated and comprehensively trained through a robust teacher education schedule to competently perform the teaching responsibility, then the guiding code to have all teachers in education institution as professionals becomes an unfulfilled vision. Consequently, the entire nation as a result becomes condemned if its education system cannot produce well-grounded technocrats that would be capable of fitting into all sectors of the national economy and competing promisingly to determine the status of the country amongst the comity of nations in global competitive standards. The critical role of the teacher in formal education as posited by Lassa (1998) is to initiate learning process, facilitate learning skills, co-ordinate learning sequence, assess learning efficiency and indeed pivot the entire educational development. These fundamental functions can be effectively discharged when the teacher possesses the necessary traits and professional competence. In other to move the teaching profession to an enviable echelon and ensure an assured prospect for our children, the essential factors and actors required to facilitate quality teacher education needs to be organized and mobilized to enhance teacher's professional development and expertise, so that the Nigerian child will be trained by professional teachers with the requisite attitude and aptitude to deliver the quality education desirous for the elevation of our children and nation.

\section{THE CONCEPT OF TEACHER EDUCATION}

The concept of teacher education has been viewed by scholars in diverse perspectives, although all the views agreed on the need for professional and career development of the teachers (and to be teachers) towards production of valuable and resourceful teachers that will guarantee effective service delivery to the society. Adewuyi and Ogunwuyi (2002) opine that teacher education is the provision of professional education and specialized training within a specified period for the preparation of individuals who intends to develop and nurture the young ones into responsible and productive citizens. Uche and Onyemerekeya (1998) view teacher education as the training given or provided in an institution to teachers to enable them acquire, inculcate and impart knowledge to their pupils or students. Teacher education according to Osuji (2009), refers to professional education of teachers towards attainment of attitudes, skills and knowledge considered desirable to make them efficient and effective in their work in accordance with the need of a given society at any point in time. It includes training and or education occurring before commencement of service (pre-service) and during service (in-service or on-the-job).

Teacher education is a programme that is related to the development of teacher proficiency and competence that would enable and empower the teacher to meet the requirements of the profession and face the challenges therein (Ugwoke etál,2012).Afe (1992)comprehend teacher education as the policies and practices designed to equip 
prospective teachers with the knowledge, attitudes and skills they require to perform their tasks effectively in the classroom, school and wider society whilst Ekpiken and Edet, (2014)conceptualized Teacher education as the complex and complete procedure of educating or preparing persons whose profession is teaching in order to play their roles as teachers towards contributing to national development. Oyeleke et'al (2013) maintains that the modes of training in teacher education are in four major components, viz: a general broad education programme to bring out depth in the intellectual knowledge of teachers. This aspect constitutes a core aspect of teacher education programme designed for all trainees. Some of the courses include basic knowledge of humanities, citizenship education; use of English, language and Communication, computer appreciation, general mathematics, and etc. The second component is the subject area specialization. In many training centres and universities, a trainer is expected to specialize in maximum of two subjects ${ }^{\text {ee }}$ combination. The third component focuses on professional courses designed to ensure that trainers are grounded in science of teaching and learning. They include courses on philosophy of education, educational psychology, sociology of education, curriculum and instruction, guidance and counselling, educational administration etc. while the last component of teacher education is practical phase designed in two modes.

The first mode is micro teaching which is experimental in nature aimed at inculcating required confidence in a classroom setting where duration of teachings and number of students per class is scaled down to a considerable size an inexperienced teacher can easily manage. The actual teaching practice is the second mode and Student-teachers are posted to schools to teach under the supervision of experienced teachers in the schools of their posting and external supervisors. The aim of teacher education as highlighted by the Nigerian National Policy on education (FGN,2004) includes :(a) Producing highly motivated, conscientious and efficient classroom teachers for all levels of our educational system (b) Encouraging further, the spirit of enquiry and creativity in teachers(c) Helping teachers fit into social life of the community and society at large and enhance their commitment to national goals(d) Providing teachers with the intellectual and professional background adequate for their assignment and making them adaptable to changing situations (e) Enhancing teachers' commitment to the teaching profession.

\section{CHALLENGES FACING TEACHER EDUCATION IN NIGERIA}

In spite of the various recommendations and reforms targeted at repositioning teacher education in the country for optimal performance, there are numerous challenges facing teacher education in Nigeria. Some of these emerged with the changing socio-economic and political condition of the time while others evolved as a result of government neglect of the education sector especially as it concerns keeping pace with emerging realities such as servicing Nigeria's growing population, education demand and needs with matching supply of education services and facilities. Inadequate funding of the education sector has been a major challenge facing the sector. Researchers, Aina (2002), Durosaro (2006), Amadi (2007); Balogun (2010) lamented over the inadequacy of fund in the education sector. It is no longer an overstatement that the Nigerian government, over the years has not been able to meet the United Nations Educational Scientific and Cultural Organization (UNESCO) recommendations for 26\% of the total budgetary allocation to the education sector. The gross underfunding is a setback to the sector in terms of project implementation. 
Another formidable problem of teacher education in Nigeria today is the lack of interest on the part of the secondary school leavers in the teaching profession because of the poor image associated with the status of teachers in the society. Durosaro (2006) maintains that the low status accorded to teachers in the country does not make students enroll and be trained as teachers while the few who enrolled did so because they had no choice. At the moment, it appears as if the system in Nigeria promotes the reservation of intellectually and financially deficient students for the teaching career. Furthermore, most teachers are not committed to the teaching job due to a number of interrelated factors like poor income, delay in payment of salaries, lack of job satisfaction. These factors are contributory to the seemingly declining attitude and commitment of teachers to their professional calling. The lack of commitment manifests in the areas of lack of enthusiasm to work; lack of concern for co-curricular and extra-curricular activities; inadequate preparation for lessons; failure to write lesson notes; careless handling of statutory records among others. (Ajayi \& Shofoyeke, 2003)

Policy inconsistencies and poor implementation. In Nigeria, policies changes frequently with almost every change in leadership. These inconsistencies in education policies constitute s challenge to quality delivery of teachers' education. The poor-quality delivery is responsible for the abysmal low performance of teachers' graduates from the institutions of higher learning in Nigeria. Anyakoha, (1994) argued that our policies are written by knowledgeable writers who have foresight and believe strongly in what they write for the future but the problem do arise in times of translating theory into practice. In like manner, Osokoya, (2012) averred that teachers' conditions of service do not hold enough incentives to attract and retain the best brains in Nigerian schools. As a result of the weakening attraction to the teaching profession and by extension the resultant dwindling enrolment in the teacher education programs, those who remain in the profession maintain relatively low social status with associated emotional inconvenience.

A critical review reveals that the standard of education in Nigeria has reduced in recent years because of the brain drain phenomenon. This syndrome is to a large extent, attributable to inadequate incentives, poorly equipped education system in an increasingly hostile working environments, inadequate social recognition, delay in payment of teachers' salaries and other entitlements among others. Another challenge to teacher education in Nigeria is that of insufficient knowledge on the use of information and communication technology (ICT).The knowledge and use of computer technology as well as the internet is a necessity for all teachers to guarantee the relevance of the system and its products in the $21^{\text {st }}$ century.Appallingly,many schools in Nigeria still operate the old traditional system with little or no adaptation to ICT (Osokoya, 2012). Additionally, a large number of untrained and half-baked personnel are still retained in the system leading to many teachers in Nigeria not measuring up to the minimum international standard. Certainly, this has socio-political and economic implications given the fact that education remains a very essential component that produces a healthy and prosperous nation.

Another key challenge affecting teacher education in Nigeria is poor supervision of instructional process in training institutions and the politicization of appointment into leadership positions in education institutions where individuals who have no background in education (as a result of ethnic, religious, political and regional affiliations) are appointed or selected as heads of education and related institutions, such misfit appointment will definitely affect the output of the leader in the discharge of his duties due to lack of basic knowledge of general principles and 
philosophies of education. Finally, the perceived corruption in the system where funds meant for the education sector are either misappropriated or diverted for personal and other uses thereby starving the education sector of the needed funds to executes its projects/programmes is also a constraint affecting teacher education in Nigeria.

\section{STEPS TOWARDS IMPROVING TEACHER EDUCATION IN NIGERIA}

Regardless of the vast challenges facing teacher education in Nigeria as earlier discussed, a lot can still be done to place teacher education in a good position to offer quality teachers that will guarantee quality education and a vibrant society. The funding of the education sector needs to be augmented and should not be left in the hands of the governments alone because education is capital expensive; the private institutions and multi-national organizations should play a contributory role in funding education programmes in Nigeria through a robust public-private partnership (Ejiogu,2003).To ensure effective utilization of funds, a proper mechanism for accountability should be instituted to ensure that all appropriated funds are utilized as planned and identified misappropriations should be treated to a logical conclusion with the perpetrators punished and looted funds recovered and rechanneled to the areas of need.

Akintidure and Ekundayo, (2012) suggested that professional teaching qualification should be made mandatory for teachers so that the code of ethics will be respected and the profession will be open to only qualified persons. To reduce the impact of the invasion of the education system by persons neither trained nor interested in teaching as a career, the Mandatory Professional Development Courses (MPCD) should be implemented by the Teachers Registration Council of Nigeria (TRCN) and other associated bodies to guarantee that teachers keep abreast of theories and practice of the profession. More so, Special salary scale like the Teachers Salary Structure (TSS) could be instituted so that teachers with educational background and long-time experience would benefit from a certain professional allowance. For teacher education to get its pride of place in this democratic dispensation there is the need for deliberate effort through societal mobilization to change the orientation of people as regards their perception of teachers and the teaching job. Teaching must be recognized as the bedrock of other professions by the government and accorded its rightful place in the society so as to attract and retain young ones into the profession. In another dimension, the teacher education curriculum needs to be reviewed so as to incorporate ICT, entrepreneurship skills and development courses to ensure that teachers are not only trained in act of self-development through continuous learning but also prepared for self-employment as a result of the growing graduate unemployment.

Akintidure and Ekundayo (2012) posit that motivation for teachers should be considered as a means of improving output and productivity in the school system. Adequate motivational incentives in terms of condition of service should be provided and the government should upgrade the working conditions of teachers to be comparable to what professional colleagues in other fields are enjoying so that teachers will be accorded the status of skilled workers rather than cheap labour. There is also the need for improvement in the level of the infrastructural facilities in schools. Ibukun (2004) advocated for modern educational gadgets like computers, modern instructional materials and packages to be introduced into the teacher education programme. It must be noted that no programme can succeed if adequate infrastructural facilities are not provided for implementation. This to a large extent depends on the level of funds made available to the system. 
Teachers on their part must show high level of dedication and commitment to their job. They should demonstrate good sense of responsibility in carrying out their duties. Regardless of the magnitude of societal negative attitude to teachers, they must not deviate from their traditional role of modelling of future leaders and creating a platform for nation building. Furthermore, seasoned educationist or education administrators with good reputation and experience should be appointed or selected as administrators or supervisor of education institutions and programmes; this will enable them to articulate policies, administer, implement, and supervise various aspects of teacher education programmes. It will be an aberration to allow none certified individuals to guide and direct the qualified and licensed professionals.

Proper training of our teachers at all levels is very important. If the nation will advance educationally and otherwise, the teachers who are the centre between knowledge and learning in our educational system should be trained and retrained on a continuous basis, in order to meet the societal needs. The entry qualification in teacher education should be standardized. Moreso, the part time mode of studies in education courses should be reviewed and restricted to only teachers presently on the job while prospective teachers should be admitted to run full time programmes to enable them have a good grasp of the principles and philosophies of education.

The Inspectorate Units should be properly equipped with qualified supervision expert that are radical enough to articulate changes within the current supervision dynamics. Retired but strong school administrators and teachers who have long years of on field experience can be assigned a vital role in ameliorating instructional challenges in the academic environment. Finally, there need for the government to consider adjusting the retirement age of teachers just as it is, in the case of judiciary and university lecturers so that best brains in the teaching profession that are wasting away due to early retirement from service can still be utilized in the education sector.

\section{CONCLUSION}

In Nigeria, teaching is an important activity that makes possible the acquisition of skills and is regarded as the most fundamental and strategic profession to produce the necessary manpower for national development. Consequently, proper training of the teacher is needed for the good of the society so that the country can boast of competent individuals whose performances will position Nigeria as an intellectual giant in Africa. Even though a lot of critical factors have been identified as setback facing teacher education in Nigeria, It is hoped that the implementation of the aforementioned steps will influence the result to be achieved, the direction to be pursed and the priorities to be recognized thereby positively changing the value system and remodeling teacher education towards meeting the aspiration of the nation to build a veritable standard of education through dedicated, competent and dependable teaching force. The teachers should to be given what they merit so that the society would in turn get what it deserves from the teachers towards building a vibrant and dependable economy. 


\section{REFERENCE}

Adewuyi J.O. and Ogunwuyi, A.O. (2002). Basic Text on Teacher Education. Oyo. Odumatt Press and Publishers.

Afe, J.O. (1992). Trends in Teacher Education: The case of colleges of Education in Nigeria. In Eimuhi J.O. and Otomewho, G.A. Access, Equity and Quality in Higher Education. NAEP Publication.

Aina OI (2002). Alternative modes of financing higher education in Nigeria and the implications for university governance. Africa Development, 27(1\&2): 236 - 262

Ajayi T, Shofoyeke AD (2003). School discipline, teacher's attitude to work and ethics of the teaching profession. In T.E. Ajayi and J. Fadipe (Eds) Skill improvement programme for effective performance of teachers in Nigerian schools. Ondo: NIEPA Printing Press. 33-54.

Akintidure, I.O and Ekundayo,H.T (2012)Teacher education in a democratic Nigeria: Challenges and the way forward. Educational Research. Vol. 3(5) pp. 429-435

Amadi MN (2007). Funding initiatives in higher education. in J. B. Babalola, G. O. Akpa, A. O. Ayeni, S. O. Adedeji (Eds) Access, Equity and Quality in Higher Education. NAEAP Publications. 543—554.

Anyakoha E.U. (1994) Strategies for Enhancing the Teaching of Home Economics in Junior Secondary School level. Nigerian Vocational Journal VII: 61-70.

Balogun AM (2010). Challenges of higher education in Nigeria: A manager's perspective. Being a paper presented at the maiden edition of the Faculty of Education Annual Lecture Series, University of Ado-Ekiti, March 22nd.

Daily Sun (2017, Feb.25th). Improving Teacher Education (editorial): p.14

Durosaro DO (2006). Teacher education in Nigeria: Past, present and future challenges. The Pacesetter: J. Oyo State College Educ. 13 (1):44-54.

Ejiogu,A.(2003). Decentralization as Panacea for Nigeria's education misadventure. The annual conference of Nigerian Association of Educational Administration and Planning (NAEAP). Ibadan, 29th - 31st October.

Ekpiken, W. E., \& Edet, A. O. (2014). The Role of Teacher Education and Nigerian Teachers In National Development: The Way Forward. Higher Education of Social Science, 7 (1), 139-143.

Federal Republic of Nigeria (2004) National Policy on Education (4th ed) Lagos: NERDC press.

Ibukun, W.O. (2004). Qualified teachers for quality education in Nigeria. Issues in Educational Foundations and Management, (1). 12-21.

Lassa, P.N (1998). 'Teacher production: Focus on Nigeria'. In R. Akpofure (ed.), the state of education in Nigeria, UNESCO. Abuja. pp. 70-83.

Nakpodia, E. D. (2012). Impediments of educational bureaucrats on teacher education in Nigeria. Global Business and Economics Research Journal, 1(2): 111-124.

Ogunyinka, E.K., Okeke T.I, and Adedoyin, R. C, (2015). Teacher Education and Development in Nigeria: An 
Analysis of Reforms, Challenges and Prospects. Education Journal. Vol.4, No.3. pp. 111-122.

Ogunjemilua, A. A and Adegboye, A. A (2014) Promoting Functional Teacher Education in Nigeria: Problems and Prospects. International Journal of Scientific and Research Publications, Volume 4, Issue 8, pp:1-7

Okebukola, B.S (1996, Jan.12th). Cries from the Nigerian Teacher. Weekly Star.P3.

Okemakinde, T., Adewuyi, J. O., and Alabi, C. O. (2013). The Place of Teacher in National Development in Nigeria. European Journal of Humanities and Social Sciences Vol. 19, No.1,

Oyekan, S.O. (2006): Foundations of Teacher Education. Ibadan. Ben Quality Prints.

Oyeleke, O., Akinyeye, CO and Opeloye, B.A (2013). A Critique of Teaching Profession and Teacher Education in Nigeria. International Journal of Humanities and Social Science: Vol. 3 No. 5; PP267-273

Osokoya, I. (2012). Teacher Education in Nigeria: Past, Present and Future Challenges. The Online Journal of Academic Leadership (Vol. 10, Issue 1).

Osuji, S. N (2009): Teacher Education Curriculum in Nigeria in the Perspective of Lifelong Education. In the Journal of International Social Research Vol 2(8) summer.

Uche, V.W. and Onyemerekeya, C.O. (1998) “Teacher Education for Nigeria Tertiary Institutions” Awka Newel Centric Publishers.

Ugwoke,SC. Ofoegbu,C.A \& Ugwuanyi,FN (2012). Quality Assurance in Teacher Education for Teacher Productivity in Anambra State. Bassey Andah Journal Vol 5 Page 195-206 